\title{
Investigation of Water Quality in Waste Fed (Poultry Droppings) Catfish Production
}

\author{
Anyadike, C.C., And B. O. Ugwuishiwu, \\ Department of Agricultural and Bioresources Engineering
}

\begin{abstract}
Study was performed in randomized block design of three by three with replication of three waste loading rates. Nine fingerlings measuring an average of $5.7 \mathrm{~cm}$ and weighing $1.105 \mathrm{~g}$ were randomly stocked and culture was treated with commercial feed, poultry droppings and a combination of the two. Each of the treatments was ranked 1,2 and 3 respectively. The fixed factors are the weeks and treatments while the dependent variables are the parameters investigated in this study which are $\mathrm{pH}$, dissolved oxygen, temperature, algae biomass and fish mortality. At the end of four weeks the study produced these result; treatment 1 - Temp 26.710C, DO 14.63mg/L, pH 9.56, algae 3, mortality 0; treatment 2 - Temp 29.14OC, DO 5.09mg/L, pH 6.98, algae 4, mortality 1; Treatment 3 - Temp 26.57OC, DO $16.69 \mathrm{mg} / \mathrm{L}, \mathrm{pH} 9.34$, algae 3, mortality 0 (these are final day values). Analysis was performed on data obtained and graphs produced which exposed the effect of these feed treatments on water quality. Hence, assist in choosing feed type that suits fish and its environment.
\end{abstract}

Keywords: - Feed, Fish, Waste, Water Quality

\section{INTRODUCTION}

The increasing cost of fish feed has made research interest to be focused on reducing cost of the most expensive ingredients by alternative protein sources. Poultry manure is a potential source of protein. It has attracted the attention of animal nutritionists all over the world because of its richness of protein, calcium (5.4\%), phosphorus as $\mathrm{K} 2 \mathrm{O}$ and magnesium as $\mathrm{MgO}(0.335 \%)$ other minerals [1,2]. Recently, fish farmers especially in the integrated farming system have been encouraged to recycle wastes from animal dung (especially poultry) as food for fish rather than discard them. Poultry manure is not only used as organic manure in the production of plankton but also directly consumed by fish in the culture system.

Although, this observation has been verified by many workers [3-5], information on the effect of the dung on water quality when incorporated into commercial fish diets, or use as a sole source of feed for catfish production are scarce. Water quality is important to fish production and survival. Most of the important water quality parameters in fish farming include: temperature, $\mathrm{pH}$ level, alkalinity, amount of dissolved gases such as oxygen and $\mathrm{CO} 2$, heavy metal concentration, acidity, total dissolved solids, nutrient levels and turbidity. Physical, chemical and biological factors of aquatic environment have significant effect on survival, growth and reproductive behavior of cattish. The objective of this work is to investigate the effect of the poultry dropping on water quality of catfish production system.

\section{METHODOLOGY}

The fish was provided with a satisfactory culture environment so that growth and conversion of feed is as efficient as possible. Nine Circular plastic tanks were used with water capacities of 25 litres. Nets were used to protect the fish from predators and from leaping out of the tanks. The chosen species were fingerlings of catfish (Clarias gariepinus), this is because of their availability in this region (eastern Nigeria) and ability to survive in moderate average temperature at certain levels. The system was set up in a randomized block design of three by three with replication of three waste loading rates. The three factors are treatment with commercial feed, poultry droppings and a combination of the two. Each of the treatments was ranked 1,2 and 3 respectively. The fixed factors are the weeks and treatments while the dependent variables are the parameters which include $\mathrm{pH}$, dissolved oxygen, temperature, algae and fish mortality. The poultry dropping collected from a battery cage was pounded with mortar and sieved. The proximate analysis of the feed are as presented on Table 1.

Table 1: Proximate Analysis of Denzegoff (fish feed) and Poultry Dropping

\begin{tabular}{|l|l|l|}
\hline NUTRIENTS & $\%$ IN NORMAL FISH FEED & $\%$ IN POULTRY DROPPING \\
\hline 1. Crude protein & $48.15 \%$ & $13.83 \%$ \\
\hline 2. Crude & $0.90 \%$ & $18.90 \%$ \\
\hline 3. Fats \& oil & $3.15 \%$ & $0.20 \%$ \\
\hline 4. Moisture & $7.90 \%$ & $4.70 \%$ \\
\hline 5. Ash & $22.50 \%$ & $32.20 \%$ \\
\hline 6. Carbohyrate & $18.70 \%$ & $49.07 \%$ \\
\hline
\end{tabular}


Nine fingerlings measuring an average of $5.7 \mathrm{~cm}$ and weighing $1.105 \mathrm{~g}$ in weight were randomly stocked in each plastic tank filled with water. Water exchange rate was $25 \%$ twice weekly to reduce the ammonia content. The fish were fed twice everyday; morning and evening at 3\% body weight, i.e. fish feed and poultry droppings given to fish weighed $0.2321 \mathrm{~g}$. Water quality parameters such as temperature, dissolved oxygen, and $\mathrm{pH}$ were monitored daily for a period of 4 weeks. These parameters were measured onsite with DO hand held meter HI9142, thermometer and pH S- 25.

The results obtained from the daily water quality monitoring were subjected to statistical analysis using Analysis of Variance (ANOVA) for a Randomized Complete Design Factorial Experiment. Detection of differences between treatments means for significant effects were obtained using Duncan's New Multiple Range Test (DNMRT) at 5\% level of probability [6]. Simple statistic was also used to represent the data graphically.

\section{RESULTS AND DISCUSSION}

The mean result of the daily water quality analysis is as presented on Table 2.

Table 2: Values of Temperature, pH, Dissolved Oxygen, Algae and Fish Mortality Rate

\begin{tabular}{|c|c|c|c|c|c|c|c|c|c|c|c|c|}
\hline \multicolumn{13}{|l|}{ Treatment l } \\
\hline Week & 1 & 1 & 1 & 2 & 2 & 2 & 3 & 3 & 3 & 4 & 4 & 4 \\
\hline Temperature $\left({ }^{\circ} \mathrm{C}\right)$ & 27.43 & 26.21 & 27.02 & 26.64 & 26.50 & 26.64 & 26.32 & 26.43 & 26.07 & 27.14 & 27.07 & 26.71 \\
\hline Dissolved Oxygen & 6.41 & 6.41 & 7.03 & 8.55 & 7.65 & 8.39 & 10.60 & 12.51 & 12.72 & 14.53 & 14.81 & 14.63 \\
\hline $\mathrm{Ph}$ & 11.37 & 10.28 & 10.81 & 9.89 & 9.69 & 9.54 & 10.10 & 8.99 & 9.71 & 9.84 & 9.5 & 9.56 \\
\hline Algae & 0 & 0 & 0 & 1 & 1 & 1 & 2 & 2 & 2 & 3 & 3 & 3 \\
\hline Fish Mortality & 0 & 0 & 0 & 0 & 0 & 0 & 0 & 0 & 0 & 0 & 0 & 0 \\
\hline \multicolumn{13}{|l|}{ Treatment 2} \\
\hline Week & 1 & 1 & 1 & 2 & 2 & 2 & 3 & 3 & 3 & 4 & 4 & 4 \\
\hline Temperature $\left({ }^{\circ} \mathrm{C}\right)$ & 27.07 & 28.86 & 26.57 & 29.33 & 28.89 & 29.36 & 29.79 & 27.73 & 28.57 & 28.75 & 27.86 & 29.14 \\
\hline Dissolved Oxygen & 6.12 & 5.06 & 5.20 & 5.28 & 5.19 & 5.45 & 5.21 & 5.95 & 5.76 & 5.39 & 5.87 & 5.09 \\
\hline $\mathrm{pH}$ & 9.78 & 8.75 & 9.27 & 8.35 & 8.27 & 7.80 & 7.64 & 7.49 & 7.32 & 6.82 & 6.51 & 6.98 \\
\hline Algae & 0 & 0 & 0 & 1 & 1 & 1 & 2 & 2 & 2 & 4 & 4 & 4 \\
\hline Fish Mortality & 0 & 1 & 1 & 0 & 0 & 1 & 1 & 1 & 0 & 1 & 1 & 1 \\
\hline \multicolumn{13}{|l|}{ Treatment 3} \\
\hline Week & 1 & 1 & 1 & 2 & 2 & 2 & 3 & 3 & 3 & 4 & 4 & 4 \\
\hline Temperature $\left({ }^{\circ} \mathrm{C}\right)$ & 26.07 & 26.57 & 25.93 & 26.43 & 25.93 & 27.00 & 26.57 & 26.57 & 26.50 & 26.14 & 27.21 & 26.57 \\
\hline Dissolved Oxygen & 7.89 & 9.24 & 6.97 & 8.73 & 9.11 & 9.43 & 14.39 & 14.69 & 17.28 & 16.90 & 16.06 & 16.69 \\
\hline $\mathrm{pH}$ & 10.54 & 10.54 & 10.42 & 10.04 & 9.99 & 9.83 & 9.85 & 9.67 & 9.79 & 9.71 & 9.35 & 9.34 \\
\hline Algae & 0 & 0 & 0 & 1 & 1 & 1 & 2 & 2 & 2 & 3 & 3 & 3 \\
\hline Fish Mortality & 1 & 0 & 0 & 0 & 0 & 0 & 0 & 0 & 0 & 0 & 0 & 0 \\
\hline
\end{tabular}

Key for algae production:

$0-$ No algae

1 - Slight green

2 - Greenish colour

3 - light green substances floating

4 - Dark green substance floating

Key for fish mortality:

0 - No death

1 - Death

The temperatures of the feed treatments were within recommended standards for fish culture for the studied period. However, there was a significant increase in water temperature for tanks treated with only poultry droppings as compared with the other two treatments (Figure 1). 


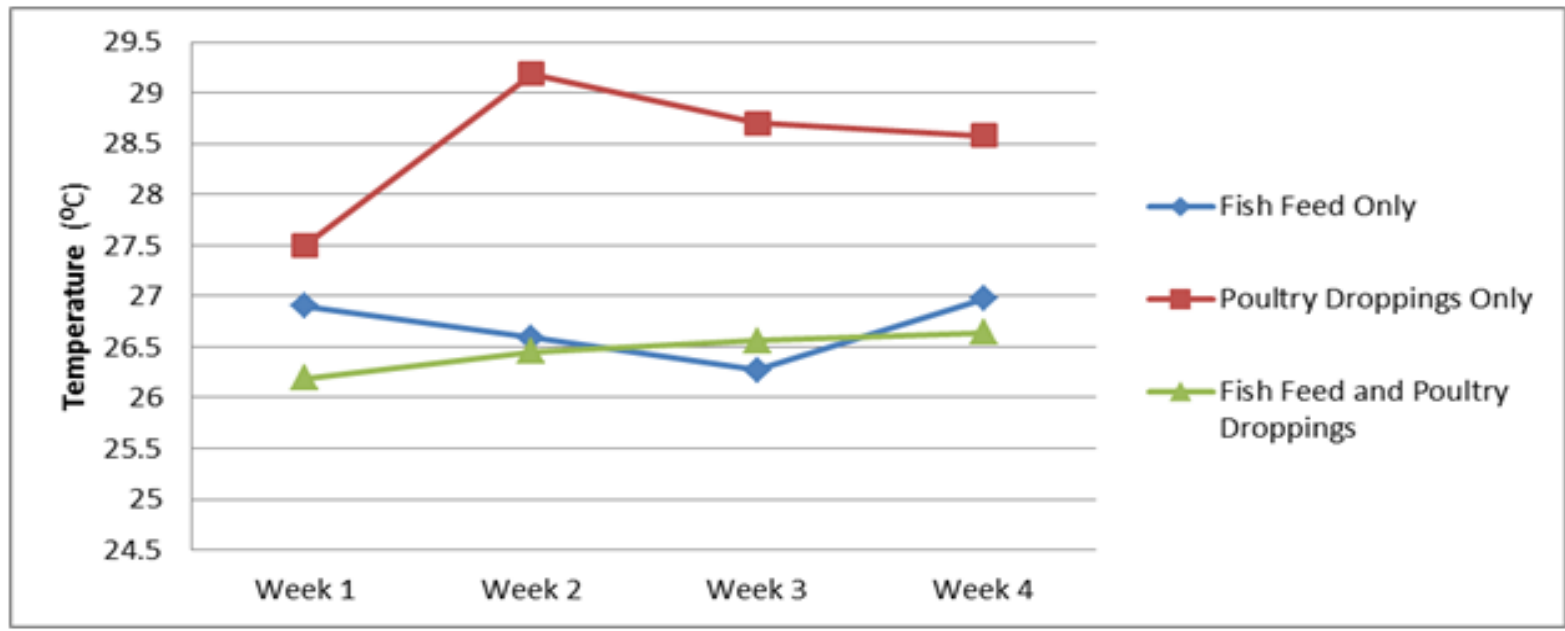

Figure. 1: The average temperature for the 3 different feed treatments

There is an obvious large oxygen demand for treatments with poultry dropping as seen in Figure 2. Treatments for fish feed and fish feed cum poultry droppings did not adversely affect DO, rather DO increased with time.

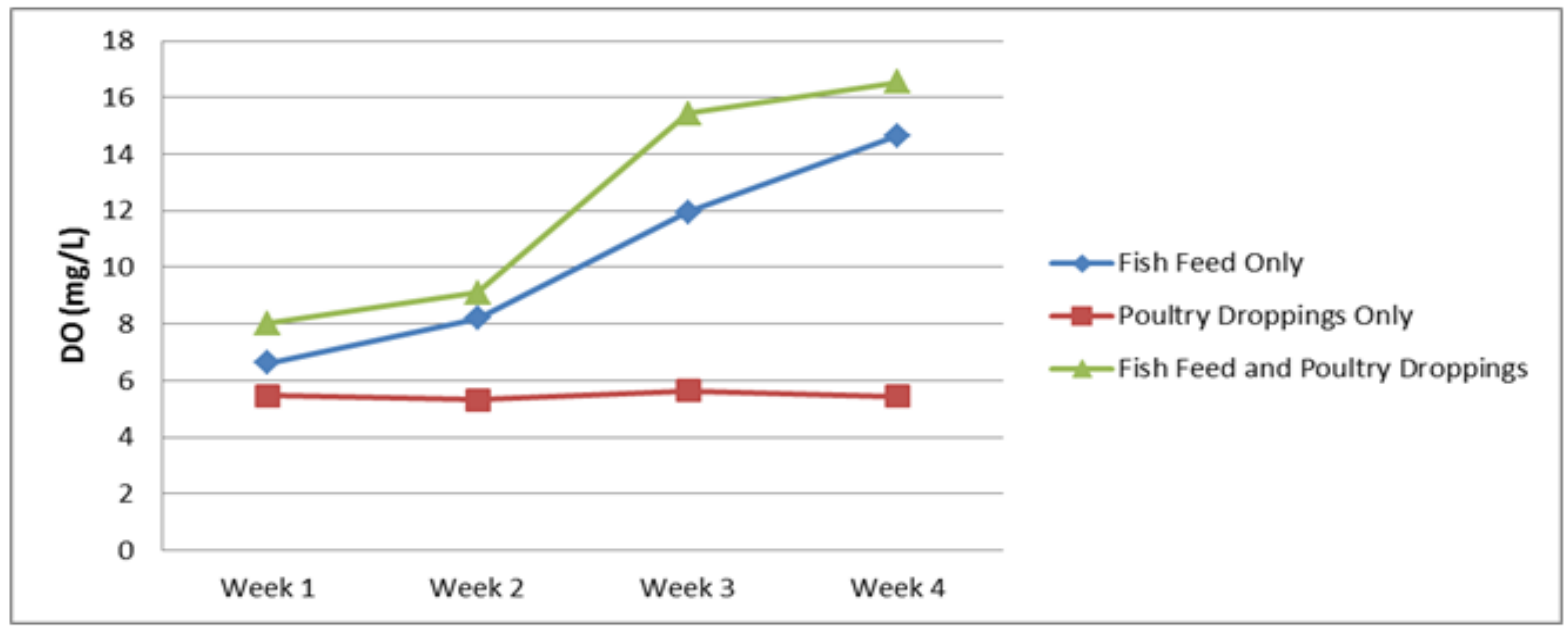

Figure 2: The average dissolved oxygen for the 3 different treatments

$\mathrm{pH}$ values generally dropped over time. Compared the poultry droppings only, the other two treatments had higher $\mathrm{pH}$ values as observed in the graph. Poultry droppings represented good relationship with $\mathrm{pH}$, though it seemed it would continue to drop to inconsiderate levels if the study had continued for longer duration.

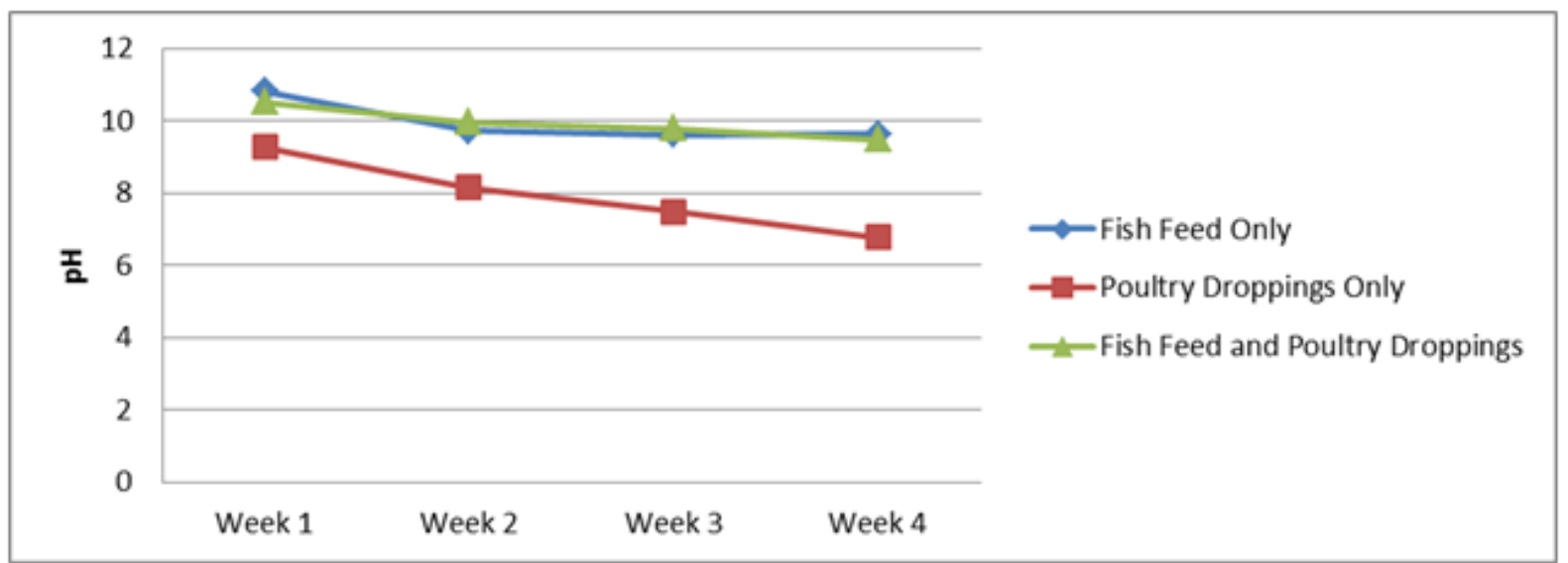

Figure 3: The average mean $\mathrm{pH}$ for the 3 different treatments 
The treatments showed almost the same trend for algae production, however the treatments with poultry dropping introduced a spike in the final week of the study. This increase also shows that longer exposure of treatment would tend to increase in algae biomass. The increase in algae biomass will compete with the stocked fish for oxygen at night for respiration; this will affect pond productivity over time.

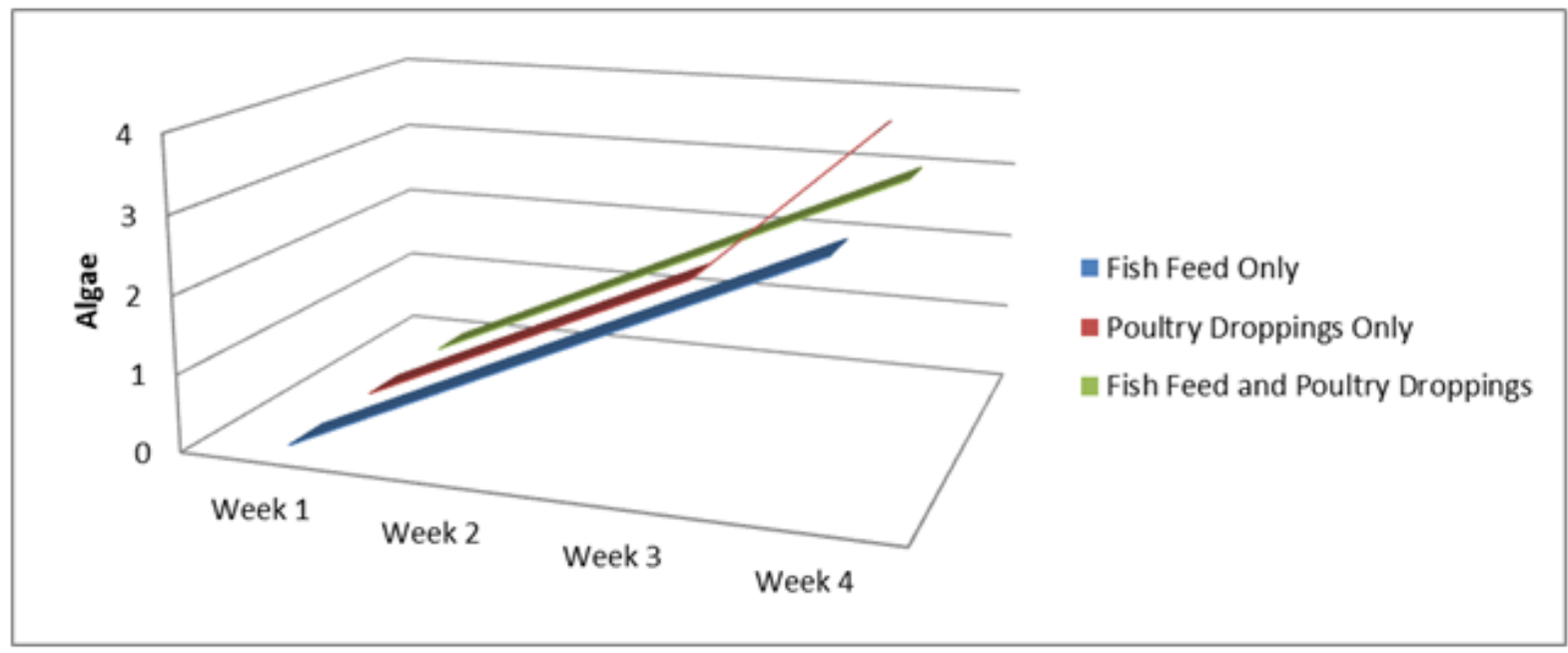

Figure 4: Mean Algae production for the 3 different feed treatments

The effect of the feed treatments on fish mortality is shown in Figure 5. The treatment of poultry dropping had a high mortality rate compare to the other treatments. Fish feed had an almost zero mortality rate while fish feed cum poultry droppings treatment had 8.3 percent mortality rate. This suggested that fish feed cum poultry can be an acceptable alternative under adequate water quality management.

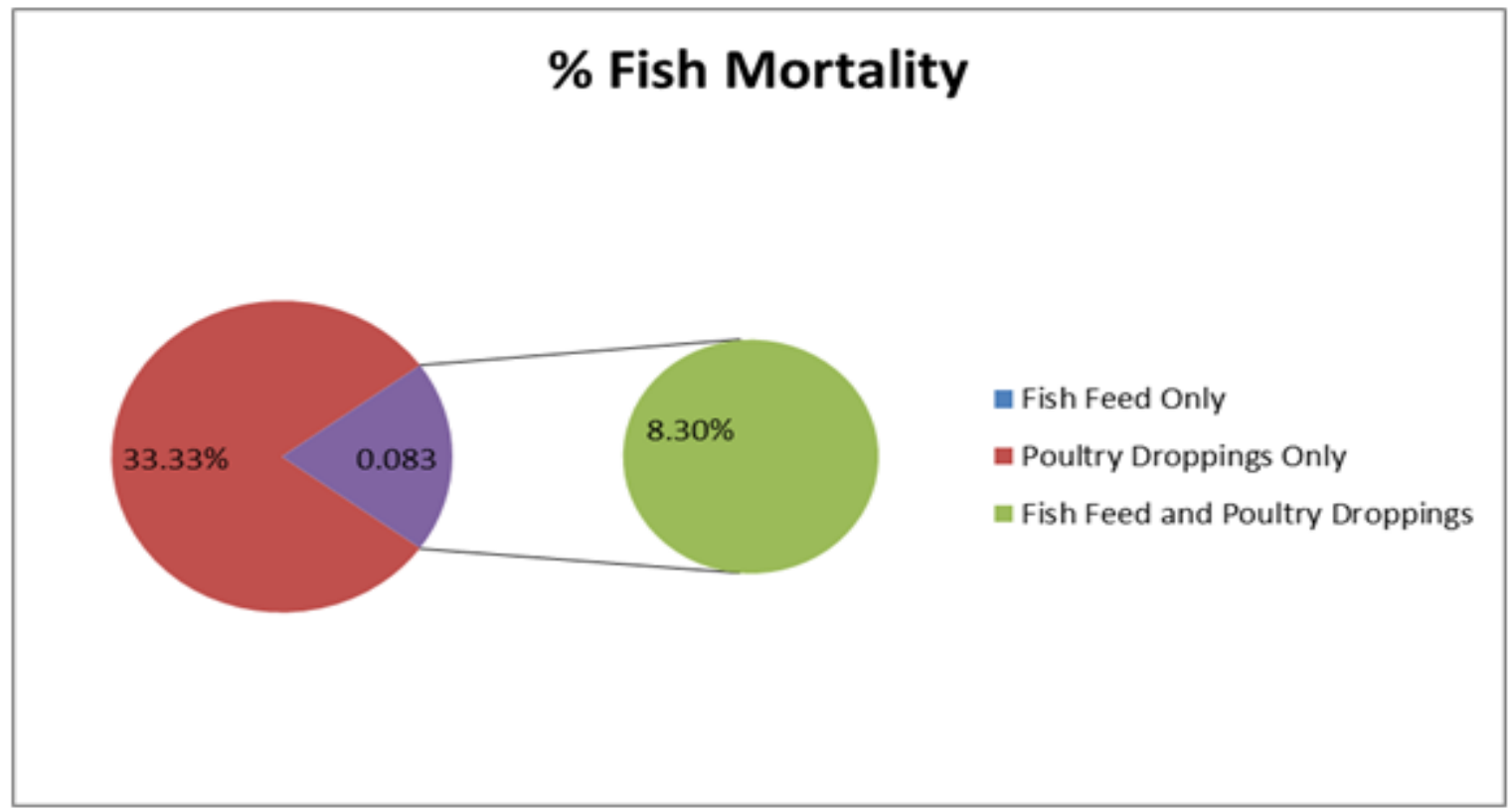

Figure 5: Percentage Fish mortality of the different feeding treatments

\section{CONCLUSION}

The water quality of the three feeding treatment in the study showed that feeding fish with poultry droppings alone is not advisable as it leads to high nutrient accumulation, increased algal bloom and fish mortality. Hence, compromising cost and still maintaining balance in quality makes the mixture of fish feed and poultry droppings a good compromise since water quality standards were not adversely affected at all and mortality was minimal. The mixture of fish feed and poultry droppings under adequate water management practices may be regarded as a better alternative, considering the high cost of commercial pelleted fish feed in our locality. 


\section{REFERENCES}

[1] Rhanjhan, S.K. 1990. Animal organic wastes. Animal Nutrition in the Tropics. Vikas Pubishing House, India: 216-217.

[2] SPFG (Sustainable Poultry Farming Group) 1994. Standardizing measures of nutrient content and density of poultry manures. Abbortford BC. www.sustainablepoultry.ca

[3] Oladosu, G.A., Ayinla, A.O., Onuoha, G.C. and Neadom, J.G. 1990. Performance of Clarias gariepinus in a polyculture with Oreochromis niloticus under integrated broiler chicken-fish farming. Nigerian Institute of Oceanography and Marine Research Technical Paper No. 65, Nigeria, 20 pp.

[4] Gavina, L.O. 1994. Pig-duck-fish-azolla integration in La Union, Phillipnes. The ICLARM Quarterly. ISSN 0116-290X. Phillipnes: 18-29.

[5] Ogumba, A.A. and Abumoye, O.O. 1998. Growth responses of Clarias gariepinus fingerlings fed live maggot from poultry droppings. In: S.O. Otubusin, N.G.O. Ezeri, O.A. Ugwumba and A.A.A. Ugwumba (Eds.), Sustainable Utilization of Aquatic/ Wetland Resources. Nigerian Association for Aquatic Sciences Selected Papers from 9th/10th Annual Conference, Nigeria: 60-68.

[6] Obi, I. U. (2002). Statistical Methods of Detecting Differences between Treatment Means and Research Methodology Issues in Laboratory and Field Experiments 2nd Edition Published by AP Express Limited Nsukka, Nigeria, $42-44$. 